TABLE 5.

APSA Membership, 1984-91

\begin{tabular}{lcccc}
\hline Year & Student & Retired & $\begin{array}{c}\text { Total } \\
\text { Individual* }\end{array}$ & $\begin{array}{c}\text { Total } \\
\text { Revenue from } \\
\text { Individuals }\end{array}$ \\
\hline $1984-85$ & 2,595 & 411 & 9,273 & $\$ 390,044$ \\
$1985-86$ & 2,589 & 432 & 9,465 & 398,408 \\
$1986-87$ & 2,775 & 439 & 9,610 & 435,393 \\
$1987-88$ & 2,718 & 450 & 9,837 & 432,902 \\
$1988-89$ & 3,054 & 489 & 10,595 & 488,721 \\
$1989-90$ & 3,436 & 488 & 11,527 & 501,486 \\
$1990-91$ & 3,656 & 519 & 11,913 & 650,434 \\
\hline
\end{tabular}

*Includes associate, life, and family memberships.

TABLE 6.

American Political Science Association Budget

\begin{tabular}{|c|c|c|c|c|c|}
\hline & $\begin{array}{r}\text { Actual } \\
1989-90\end{array}$ & $\begin{array}{r}\text { Budget } \\
1990-91\end{array}$ & $\begin{array}{r}\text { Actual } \\
1990-91\end{array}$ & $\begin{array}{r}\text { Budget } \\
1991-92\end{array}$ & $\begin{array}{r}\text { Revised } \\
\text { Budget } \\
1991-92\end{array}$ \\
\hline \multicolumn{6}{|l|}{ REVENUE } \\
\hline \multicolumn{6}{|l|}{ Membership } \\
\hline Professional & 432,965 & 520,000 & 553,905 & 546,000 & 576,108 \\
\hline Student & 55,933 & 90,000 & 85,038 & 85,000 & 88,400 \\
\hline Family & 910 & 2,000 & 1,875 & 1,800 & 2,000 \\
\hline Life & 4,085 & 2,000 & 1,700 & 1,000 & 1,000 \\
\hline Associate & 7,593 & 8,000 & 7,916 & 8,000 & 8,000 \\
\hline Institutional & 305,345 & 380,000 & 380,996 & 385,000 & 385,000 \\
\hline Total Membership & 806,831 & $1,002,000$ & $1,031,430$ & $1,026,800$ & $1,060,508$ \\
\hline Administrative & 59,158 & 80,000 & 61,281 & 70,000 & 60,000 \\
\hline Annual Meeting & 109,670 & 127,000 & 143,585 & 135,000 & 150,000 \\
\hline \multicolumn{6}{|l|}{ Advertising } \\
\hline APSR & 93,341 & 101,000 & 100,437 & 100,000 & 110,000 \\
\hline PS & 10,966 & 14,000 & 8,827 & 16,000 & 14,000 \\
\hline Program & 53,559 & 57,000 & 62,846 & 62,000 & 62,000 \\
\hline Exhibits & 101,091 & 100,000 & 107,141 & 100,000 & 115,000 \\
\hline Political Science Teacher & 4,398 & 2,000 & 946 & 0 & \\
\hline Total Advertising & 263,355 & 274,000 & 280,197 & 278,000 & 301,000 \\
\hline Dividends/Interest & 201,180 & 200,000 & 101,185 & 190,000 & 170,000 \\
\hline \multicolumn{6}{|l|}{ Sales } \\
\hline Back Issues & 2,568 & 3,000 & 1,019 & 3,000 & 2,000 \\
\hline Mailing Lists & 64,606 & 60,000 & $\begin{array}{l}66,761 \\
28,399\end{array}$ & 60,000 & 70,000 \\
\hline $\begin{array}{l}\text { Panel Paper, JDB, other } \\
\text { Reprints }\end{array}$ & $\begin{array}{r}21,232 \\
3,889\end{array}$ & $\begin{array}{r}22,000 \\
4,000\end{array}$ & $\begin{array}{r}28,399 \\
3,837\end{array}$ & $\begin{array}{r}25,000 \\
4,000\end{array}$ & $\begin{array}{r}25,000 \\
4,000\end{array}$ \\
\hline $\begin{array}{l}\text { Reprints } \\
\text { State of the Discipline }\end{array}$ & $\begin{array}{l}3,889 \\
6,324\end{array}$ & $\begin{array}{l}4,000 \\
3,000\end{array}$ & $\begin{array}{l}3,831 \\
4,815\end{array}$ & $\begin{array}{l}4,000 \\
1,000\end{array}$ & $\begin{array}{l}4,000 \\
1,000\end{array}$ \\
\hline $\begin{array}{l}\text { State of the Discipline } \\
\text { Style Manual }\end{array}$ & $\begin{array}{l}6,324 \\
3,596\end{array}$ & 3,000 & 2,172 & $\begin{array}{l}1,000 \\
3,000\end{array}$ & $\begin{array}{l}1,000 \\
2,000\end{array}$ \\
\hline Instructional Materials & 0 & 17,000 & 25,830 & 50,000 & 13,500 \\
\hline Project '87 Publications & - & - & 3,635 & - & 1,000 \\
\hline Minority Identification & 0 & 0 & 1,740 & 1,000 & 1,000 \\
\hline Total Sales & 102,215 & 112,000 & 138,208 & 147,000 & 119,500 \\
\hline Departmental Service & 144,819 & 150,000 & 190,146 & 167,150 & 167,150 \\
\hline Rent & 97,258 & 100,800 & 100,217 & 110,000 & 110,000 \\
\hline Personnel Placement & 62,551 & 65,000 & 67,802 & 65,000 & 68,000 \\
\hline Section Dues & 27,897 & 30,000 & 28,226 & 31,000 & 30,000 \\
\hline Royalties & 13,219 & 10,000 & 14,403 & 7,500 & 14,000 \\
\hline Miscellaneous & 3,620 & 3,000 & 1,438 & 3,000 & 2,000 \\
\hline TOTAL REVENUE & $\$ 1,891,773$ & $\$ 2,153,800$ & $\$ 2,158,118$ & $\$ 2,230,450$ & $\$ 2,252,158$ \\
\hline \multicolumn{6}{|l|}{ EXPENSES } \\
\hline \multicolumn{6}{|l|}{$\begin{array}{l}\text { Publications } \\
\text { APSR }\end{array}$} \\
\hline Printing & 166,308 & 185,000 & 167,592 & 194,250 & 176,000 \\
\hline Postage & 26,121 & 30,000 & 28,800 & 31,500 & 36,000 \\
\hline Salaries & 81,193 & 80,000 & 73,326 & 84,000 & 80,000 \\
\hline
\end{tabular}

tion's portfolio with the sale of Northeast Investors Trust.

Revenue declines were offset by revenues from sales and departmental services. Sales in FY90-91 rose by $35 \%$ over the previous fiscal year. Finally, annual meeting revenue increased by $40 \%$ over $1989-90$, showing one consequence of the record meetings we have experienced over the past years. Needless to say, the larger meetings have also increased expenses substantially.

All in all, revenues were robust and exceeded budget projections.

\section{Expenditure Trends}

Despite the broad range of programs the Association is responsible for, the growth in expenditures has been contained within acceptable limits (Tables 2 and 4). Publication costs continue to increase due to the inflation of paper costs. Likewise, larger annual meetings have increased the costs of the annual meeting.

The increase in general operating costs over the past two years reflects rising health care costs, higher building maintenance costs, and higher paper and supply costs. A detailed accounting of APSA's budget and salary figures are displayed in Tables 6 and 7.

\section{Summary}

The Association's budget and endowed funds (Table 8) show a dynamic organization on a solid financial foundation guaranteed to support it into the next century.

\section{Forty-Six Congressional Fellows to Begin 1991-92 Program in Early November}

Winners of the competition for the 1991-92 Congressional Fellowship Program will begin their general orientation on November 6 . In addition to the political scientists, journalists and federal executives announced in the September 1991 issue of $P S$, the following scholars and medical professionals will spend nine months working in congressional offices: 


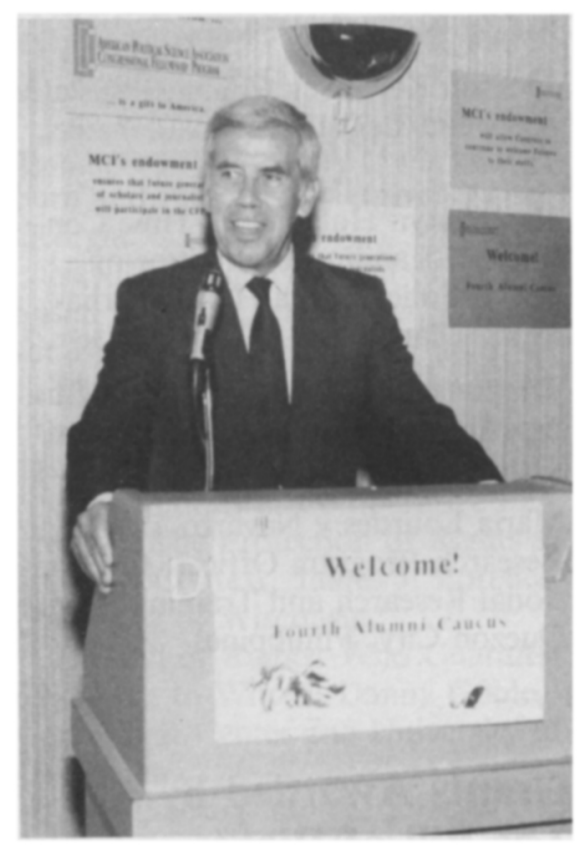

Senator Lugar honored by Congressional Fellowship Program.

\section{Robert Wood Johnson Health Policy Fellows}

Kenneth B. Chance, D.D.S., Associate Professor of Endodontics and Assistant Dean for External Affairs and Urban Resource Development, University of Medicine and Dentistry of New Jersey-New Jersey Dental School, Newark

Robert G. Frank, Ph.D., Associate Professor and Associate Chairman, Department of Physical Medicine and Rehabilitation, University of Missouri School of Medicine, Columbia

Jay S. Himmelstein, M.D., M.P.H., Director, Occupational Health Program, and Associate Professor, Department of Family and Community Medicine, University of Massachusetts Medical Center, Worcester

Philip J. Hofschire, M.D., Professor, Director of Pediatric Cardiology, and Vice Chairman for Clinical Affairs, Department of Pediatrics, University of Nebraska Medical Center, Omaha

Charles L. Rice, M.D., Surgeon-inChief, Harborview Medical Center, and Professor and Vice-Chairman, Department of Surgery, University of Washington School of Medicine, Seattle

Steven P. Ringel, M.D., Professor,
TABLE 6. (continued)

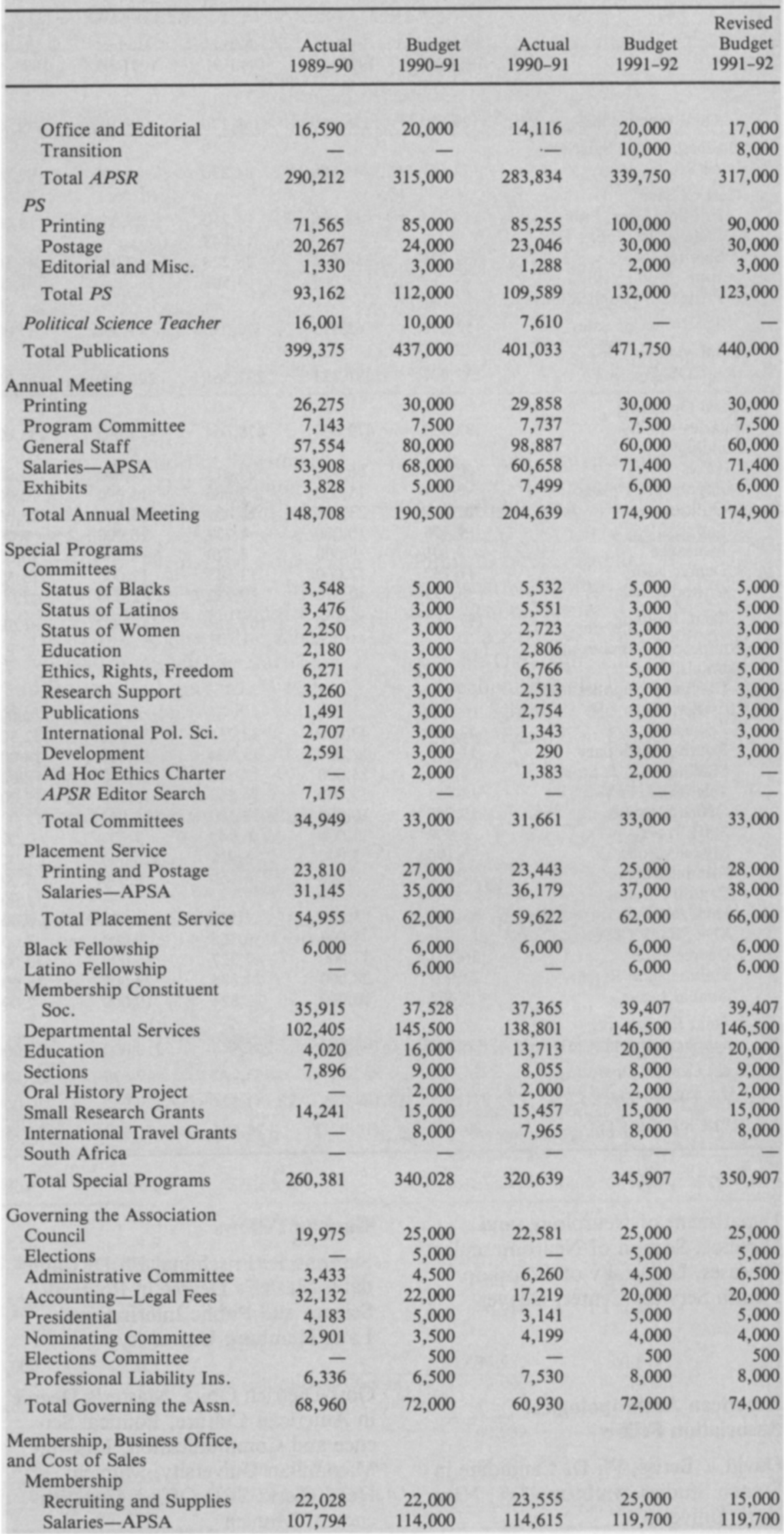




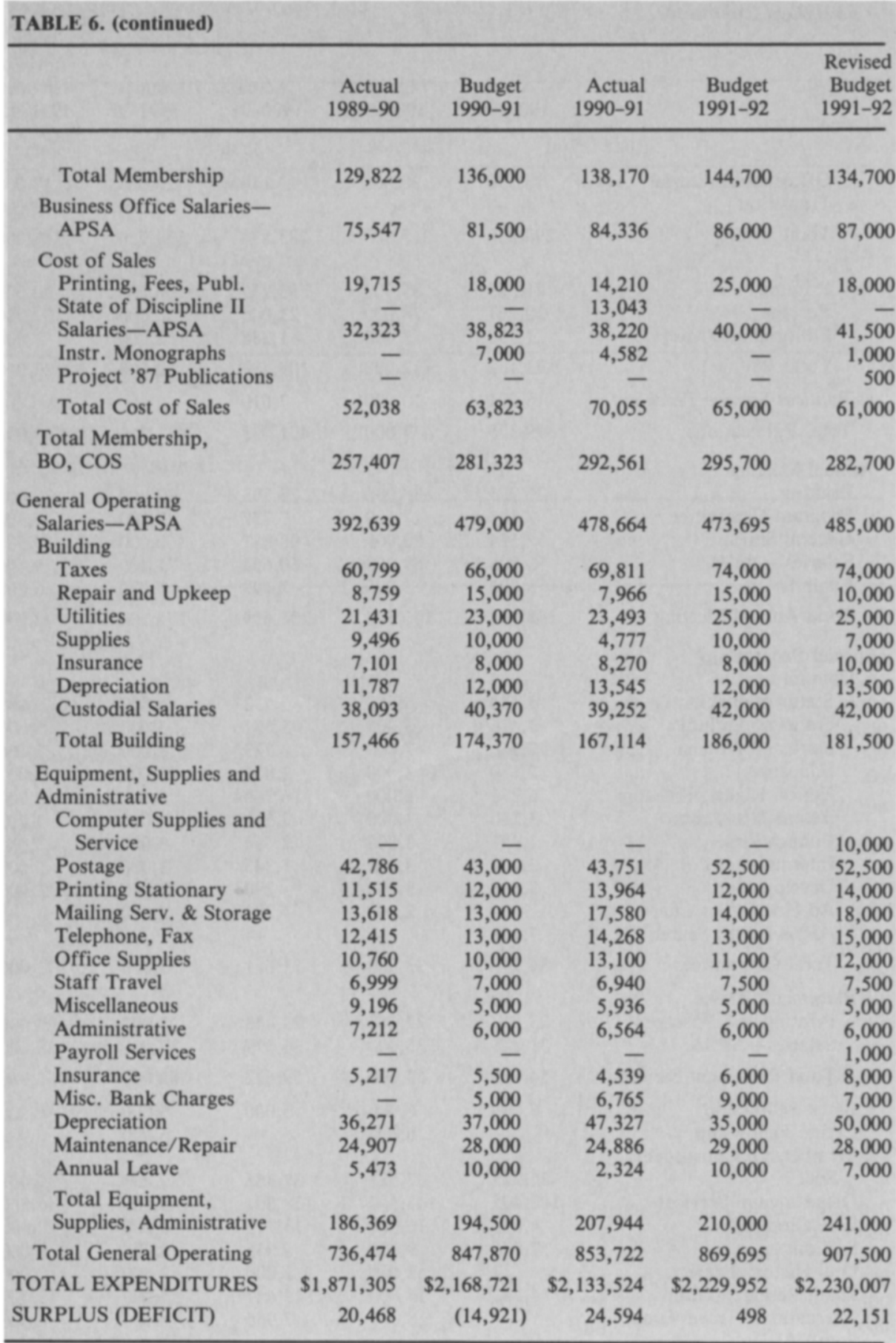

Department of Neurology, and Director, Section of Neuromuscular Diseases, University of Colorado Health Services Center, Denver

\section{American Anthropological Association Fellow}

David I. Beriss, Ph.D. Candidate in French Studies/Anthropology, New York University

\section{German Fellows}

Susanne R. Frischling, Ph.D. Candidate, Master's Degree in Political Science and Public International Law, Hamburg University

Gotz-Dietrich Opitz, Master's Degree in American Culture, Political Science and Communication, LudwigMaximilian University, Munich; Head Clerk, SPD Office, Constituency of Munich

\section{Asia Foundation Fellows}

Jackson Ke-Čheng Chang, Legislative Assistant, Legislative Yuan, Taipei, Taiwan

Hashjbatyn Hulan, Full-Time Consultant, Standing Committee on Social Policy, Baga Hural (Parliament, Ulan Bator, Mongolia

Thanong Khanthong, Assistant Business Editor, The Nation, Bangkok, Thailand

Maria Lourdes y Navarro Tiquia, Research Program Officer, Congressional Research and Training Service, Quezon City, Philippines

\section{Grants Awarded by The Bill of Rights Education Collaborative}

The Bill of Rights Education Collaborative, a joint program of the American Political Science Association and the American Historical Association, is supported by The Pew Charitable Trusts. Its goal is to strengthen pre-college education about constitutional rights by providing teachers with a range of collaborative professional activities. To this end, the program has awarded grants, on a competitive basis, to support these activities. A complete description of The Bill of Rights Education Collaborative was featured in PS: Political Science \& Politics, March 1991, pp. 104-06. Now, with the grant competitions concluded, lists of the grantees who are conducting short courses for teachers and the high school teachers who received mini grants for their own special projects follow.

\section{Short Courses}

The Bill of Rights and the States, Michael R. Zuckert, Carleton College.

Celebrating the Bill of Rights:

Civil Liberties at Home and Abroad, Jerome O'Callaghan, Texas Tech University.

Civil Rights and Civil Liberties Under the Bill of Rights, Henry S. Cohn and Denise Wright Merrill, Connecticut Consortium for LawRelated Education with the Univer- 